\title{
Picturing Urban Subterranea: Embodied Aesthetics of London's Sewers
}

\section{$\underline{\text { Abstract }}$}

As cities around the world are tunnelled and hollowed to new depths, geographers are giving increasing attention to infrastructure in the context of verticality, often framed by urban planning or geopolitics. This paper responds to calls from geography and the wider geohumanities for ethnographic and aesthetic consideration of vertical infrastructures by reflecting on London's sewer system as a site of embodied engagement and creative imagination. Once venerated by the press and public as engineering, medical and aesthetic triumphs, London's sewers are thought to have morphed into sites of ubiquitous obscurity. This paper counters this understanding by considering bodies, technologies and activities through time that have shaped imaginations of London's main drainage, including the work of contemporary urban explorers. I argue that although the current aestheticisation of infrastructural spaces in London is connected to particular technologies, politics and geographical concerns of the present, it also echoes body-space interventions and affects across a 150-year span. This aesthetic legacy is a crucial pillar in our understandings of urban verticality.

Keywords: Photography, Sewers, London, Urban Exploration, Aesthetics, Underground 
Geographic Aesthetics of Subterranean Infrastructure

"The city needs places of solace, calm, order and beauty - even prettiness. But prettiness and concealment are anaesthetic. The urban mind needs its regular confrontations with tangle, too, a bracing shock that places the world in perspective and informs us, without either warmth or rancour, that our lives are enmeshed in a vital mechanism."

- Willy Wiles (2014: np)

The London sewers made news in 2013 when a "fatberg" of solidified grease, oil and wet wipes blocked a 2.4-metre pipe under Kingston. It had to be dislodged with highpressure water over the course of three weeks (BBC, 2013). Video footage of the process was both horrifying and strangely alluring. On evenings soon after, troops of Thames Water workers could frequently be seen on the north end of Blackfriars Bridge, near the southern outfall of the River Fleet, lowering dozens of people on ropes into a sewer lid in bright white boiler suits. Their goal was to convince people, by showing them in person, that the entire London sewer system was overburdened and badly in need of upgrade. Taxpayers were being asked to support the construction of a new $£ 4.2$ Billion London Tideway Tunnel were understandably cynical. Yet sewers also pique curiosity. Into the late hours of the night, passing pedestrians not on the tour lurked, peeking into the depths of the open manhole over the temporary barriers, peppering the water workers with the obvious questions: "What's down there?" "Does it stink?" "Can I see it too?" 
Public interest in the infrastructures that have sustained urban existence in London over the past 150 years is seemingly insatiable. And yet, if these system are functioning as intended, they are meant to become "absorbed into the background" and ignored (Mau, 2003: 3-4). Hinchliffe (1996: 665) has called this process "black boxing", where "the term 'black box' refers to facts and artefacts that have achieved (temporary) stability, so much so that the controversies surrounding their adoption have to a large extent been erased."

As part of a wider "vertical turn", geographers have been pulling back the curtain on infrastructure, revealing urban undergrounds as deep, tangled conduits of connections and flows and as sites of expansionism, insurgency and social negotiation (see for instance Butcher, 2011, Dobraszczyk et al., 2016, Elden 2013, and Graham 2016). Perhaps unsurprisingly, many accounts of urban undergrounds by geographers and urbanists proffer a rather distanced perspective on the human-built underground. Here I recast undergrounds as potential sites of creative participation following Peter Adey's (2013: 52) suggestion that there are "...other ways of thinking about volumes that appear more open, more plural imaginaries that might not only describe but offer alternative volumes to inhabit." I suggest that sensory indulgences afforded in infrastructures open out a political aesthetics of verticality which also responds to Andrew Harris' recent call to emphasise "the importance of pursuing ethnographic detail to open up the variety of experiences, imaginaries and practices of vertical urban life..." (Harris, 2015: 602). The particular ethnographic detail I provide here is based on a number of expeditions into London's sewer system with urban explorers. This methodological trajectory triggered a recasting of conceptual concerns in relation to existing work on sub-urban verticality. 
As Stephen Graham outlines in the introduction to Disrupted Cities: When Infrastructures Fail, geographers have engaged with infrastructure in three ways. First, systems have been framed through assemblage theory and actor-network theory as "complex assemblages that bring together all manner of human, non-human and natural agents into a multitude of continuous liaisons" (Graham, 2009: 11). Second, through the lens of political ecology, these networks have been perceived to blend the social, the technical and the natural through processes of cyborginization (Gandy, 2005). Finally, the politicization of infrastructure, thinking about questions of access and supply, frailty and security have undermined tendencies to relegate "...infrastructures to an apolitical context or backdrop, as not noteworthy of attention, too hidden from view" (McFarlane and Rutherford, 2008: 364, cited in Graham 2009: 13).

While these accounts are all pillars of subterranean geographies, so too are subterranean aesthetics. Matthew Gandy's engagement with the $19^{\text {th }}$ century Parisian photographer Félix Nadar is of particular interest here. Nadar, working from the $1850 \mathrm{~s}$ to $1870 \mathrm{~s}$, created photographs of the Paris sewers from long exposures (some up to 18-minutes) using electric magnesium lighting, many with mannequins in frame for scale. Gandy makes it clear that sewers were the site for some of the first underground photography in history and that these photographs were not just about documentation of the humanbuilt underground, they were components of an aesthetic that melds the three concerns outlined above:

The extension of photography into the underground city not only radically extended the possibilities for the meticulous visual documentation of 
hitherto unknown places and spaces, but reinforced the ambiguous role of modern technologies in providing an illusion of complete control and comprehension of complex urban societies. In photographing the sewers, Nadar contributed powerfully to new ways of seeing and understanding the city, by challenging a series of metaphorical axes ranging across light, cleanliness, verticality, knowledge and control (Gandy, 1999: 26).

In Gandy's account, the power and politics of the vertical are evident, but so to are narratives of aesthetics and participation, where he suggests that underground photography contributed to "new ways of seeing and understanding the city". Many Parisians, enticed by Nadar's photography, visited the sewers themselves to take boat rides down the underground sewage channels. As Hawkins and Straughan suggest, "more abstract understandings of aesthetics [are] informed by geographical imaginaries of distance and proximity, or surface and depths" (Hawkins and Straughan, 2015: 9). With that in mind, what I want to offer here through a reading of, and proximal engagement with, the London sewers, contributes to a vertical imagination where desires for unique sensory experiences intersect with attempts to encounter and relay affective qualities of infrastructure etched with time. This process exposes aesthetics as politically potent, following Rancière:

...aesthetics can be understood in a Kantian sense - re-examined perhaps by Foucault - as the system of a priori forms determining what presents itself to sense experience. It is a delimitation of spaces and times, of the visible and the invisible, of speech and noise, that simultaneously determines the place and the stakes of politics as a form of experience. Politics revolves around 
what is seen and what can be said about it, around who has the ability to see and the talent to speak, around the properties of spaces and the possibilities of time." (Rancière, 2006: 13)

I extend consideration of Gandy's aesthetics of subterranean infrastructures through contemporary practices of urban exploration, where imagery acts less as documentary evidence and more as a heuristic device for triggering moments of infrastructural imagination, ruptures of connectivity, when "the town exists only as a function of circulation and of circuits; it is a singular point on the circuits which create it and which it creates" (Deleuze, 1997: 297). Those circuits, I argue, need to be read not simply across space (whether horizontal or vertical) but through time, a "continual creation of heterogeneous durations of being" (McCormack, 2012: 619) from pre-construction conceptions to future imaginations. Subterranea, and its narrative trappings, serve as foci for embodied imaginaries, positing a potent politics of image-making that continues the work of reframing subterranean space as less out-of-sight, off-limits and atemporal and more as a potential site for visceral encounter entangled with aesthetic registers of the past and future. 
Visualising inconceivable scale

The expanding subterranean metropolitan world ... links city dwellers into giant lattices and webs of flows which curiously are rarely studied and usually taken for granted.

- Stephen Graham (2000: 271)

The construction of the London sewers, 150 years ago, was an intensely visual and at times participatory public project before they came to be rendered "hidden". Although reforms regarding sewers, waterways and waste date back to the $15^{\text {th }}$ Century in Britain (with a nod to Henry VIII's 1531 Bill of Sewers), drains - as a static and co-ordinated physical municipal infrastructure - did not exist until the $19^{\text {th }}$ century. Rather, domestic sewage was offloaded into cesspools collected by "night soil men" for use as fertilizer (Dobraszczyk, 2009). Much effluvium ended up being dumped into London's local rivers, like the Fleet, which was rendered, in effect, an open sewer. By the 1840s, these piecemeal infrastructural systems were collapsing under the weight of two million inhabitants and a rapidly expanding city, leading to a catastrophic cholera epidemic, among other issues (Hardy, 1984).

Sir Edwin Chadwick, a champion of sanitary reform, published a report in 1842 stating that freedom from disease would require sanitisation linked to free flow, rather than stagnant cesspools (Chadwick, 1842). The urban body, like the body of the city, he insisted, must internally circulate, without clogs, preventing the build-up of miasma, a noxious form of "bad air", which he maintained harboured and transferred disease. Chadwick's ideas about circulation were influential in the setup of the Metropolitan 
Commission of Sewers in 1848. If architecture and the built environment is a reflection of what we know, then it comes as no surprise that we have envisioned infrastructures as corporal simulacra with sweating porous brick linings, junctions that pump and regulate passage and sewerage pipes of various size conducting flow to extremities (Vidler, 1990). However, when Sir Joseph Bazalgette took over as Chief Engineer to the Metropolitan Board of Works, tasked with building the new system after the Great Stink, he had different plans (Ackroyd, 2012). Bazalgette, who believed circulation also circulated disease, wanted to pump all the sewage out of the system, into the Thames, away from the city (Cook, 2001). Instead of circulation, he wanted efficient perpetual one-way flow, a constant urban purge.

Once approved, Bazalgette's ambitious plan began with the construction of five interceptor sewers, running east to west across London. These would connect to four pumping stations at Deptford, Crossness, Abbey Mills and Pimlico, where sewage could be dumped into the Thames beyond the $19^{\text {th }}$-century city boundaries. London's new main drainage system was described in the 1861 Observer as "the most extensive and wonderful work of modern times", comprised of 82 miles of interceptor sewers, over 1,000 miles of smaller sewers, interconnections into the old local rivers and ditches, hand-dug by labourers or "navvies", and the precise placement of 318 million bricks (Ackroyd, 2012: 79-80). The cost and scale of the work was unprecedented: 1859 preconstruction estimates sat at around $£ 3,000,000$ (Rule, 2012: 27).

The Victorian public seemed equally enthralled and frustrated by the public works taking place around them from 1859-1865. As Dobraszczyk writes, "in the mid-19 century, [sewers] were almost a national obsession and were related to a host of 
concerns, some of them technical but others that were moral, utopian or even theological" (Dobraszczyk, 2009: 11). These tensions had to do with long-held associations between subterranea and malevolent forces (Pyke, 2005). However, many also celebrated the arrival of a more "modern age" which they thought would lead to emancipation from ill health and a reduction in manual labour though the efficiency of technology (Kaika and Swyngedouw, 2000). What was being constructed, many believed, was a better-functioning urban body.

However part of the allure of subterranea was more conceptual: it was that the future was being built, a future that felt like an experiment in process all around them. People were enthralled not only by the fervour of the urban overhaul but by the idea that tunnelling would allow parallel events to take place on the same vertical axis as urban processes moved underground. For the first time in history, multiple places could be within one space; the city would forevermore have to be imagined and encountered vertically. As Rosalind Williams writes,

The cosmos of modern technology, as much as that of ancient mythology, has a vertical structure. As it reached upward in the shapes of skyscrapers, railway bridges, oil rigs, and missiles, it also sank into the earth in building foundations, railway tunnels, oil wells, and missile silos... The triumphs of modern industrial and urban life arise from connections buried below the surface of the earth. These structures rest on hidden infrastructures" (Williams, 2008: 52).

Urban spatial reconfigurations, as in Paris, were made enticing through stories and visualisations distributed by publications that attempted to elevate the works onto the 
transcendental register of the industrial sublime (Dobraszczyk, 2005). As Dobraszczyk (2007: 15) describes in detail, the London sewers were, initially, an immensely visible project, both physically and conceptually. There were maps, plans, drawings, photographs, books and illustrations of their construction to be found in media outlets like the Illustrated London News (ILN). Figure 1, for instance, depicts navvies in the bottomed-out Fleet Sewer excavation, flanked by carefully laid brick and shored up with timber, crossed 10 metres up or so by an old shallow pipe, which, we must assume, was carefully dug around. The depth of the scene, stretching the length of the newspaper page, suggests something more-than-human, an almost inconceivable scale.

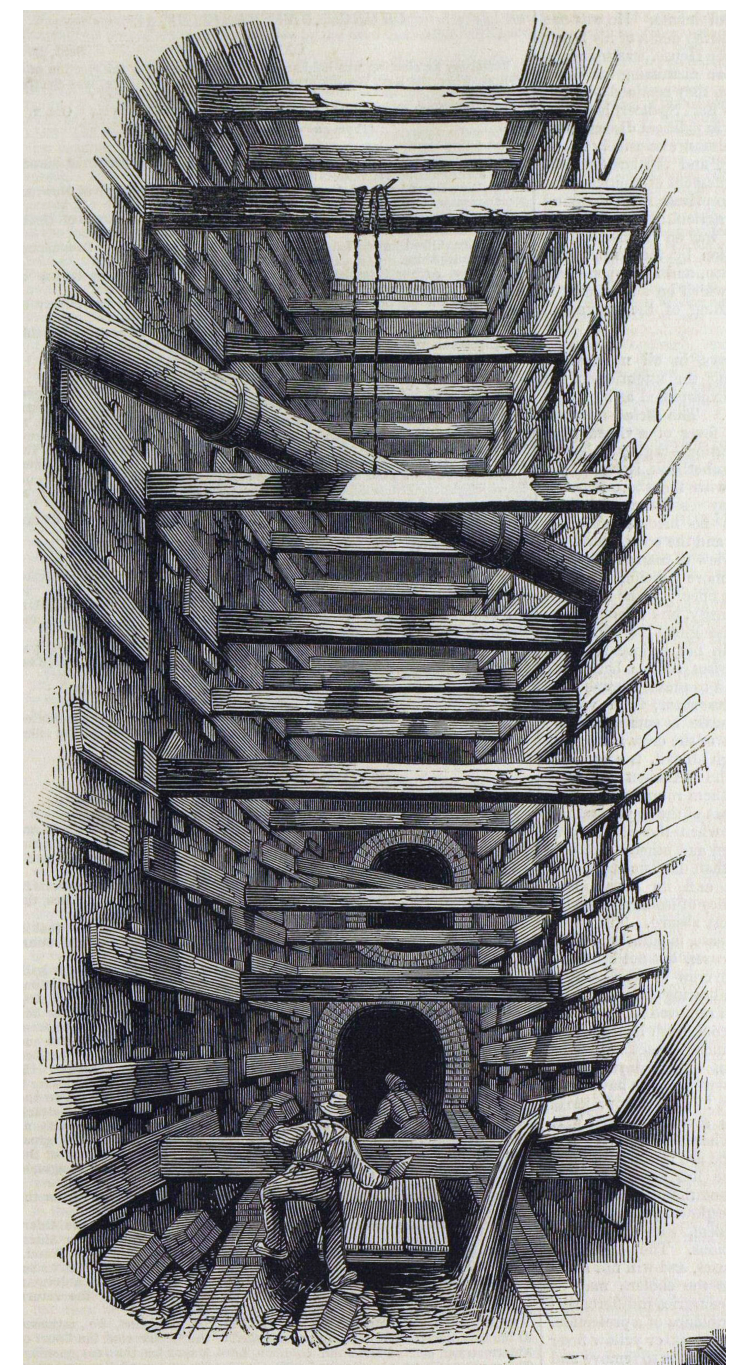

Figure 1. The Construction of Fleet Sewer, Illustrated London News, 4th Oct 1845, p. 213 (Image via Wikimedia Commons) 
Williams suggests that a sublime aesthetic was being put to work on Victorian audiences. The images produced suggested a new vertical spatiality of both tranquility and terror, where "sublime terror is aroused by anticipated, not actual pain and danger" (Williams, 2008: 85). In the same way that landscape paintings in the sublime tradition were produced to overwhelm the viewer with awe, Bazalgette wanted to instill in the mind of the viewer a sense that subterranean infrastructural technologies were a new realm of the sublime, that human beings could produce cultural landscapes as beguiling as anything found in the natural world. In this light, we might view these sewer images in the tradition of Piranesi's $18^{\text {th }}$ century Imaginary Prisons, though, importantly, the images of the sewers connected to places one could potentially physically encounter.

These depictions were central to a suggestion that a new age was being ushered in that was incomprehensible because it exceeded calculation. This was of utmost importance to retaining public support, for, as Fiona Rule outlines, the day-to-day construction of the sewers was immensely frustrating for local residents. "Roads became impassable, mud oozed across the streets and householders were forced to put up with constant noise during daylight hours" (Rule, 2012: 33).

Photographs, also publically circulated, depicted Bazalgette and his employees apparently hard at work in deep cuts, as seen in Figure 2. Of course these photos, as is made clear from Gandy's discussion of Nadar's work, would have been long exposures, requiring everyone in frame to stand still for a number of minutes, even taken through the collodion wet plate process, the new photographic technology of the time. These 
photos were in a sense very much "staged". ${ }^{1}$ Through the physical act of infrastructural overhaul, the deployment of new photographic and illustrative technologies documenting the process, and the large scale distribution of such creations, a deeper understanding of Bazalgette's bricks lies in the affective aesthetic, created to do exacting forms of work on audiences.

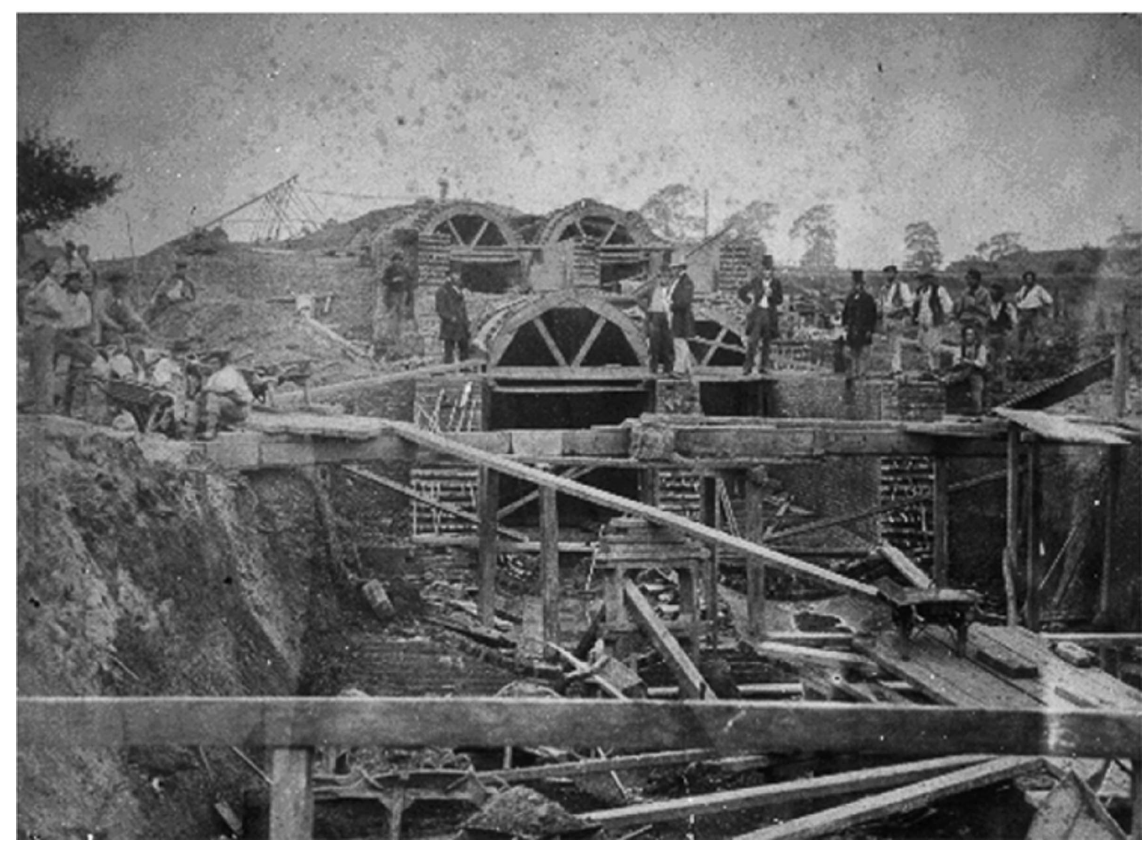

Figure 2. Photograph of Sewer Tunnels at Wick Lane, East London, 1859 (Image via Wikimedia Commons)

Williams suggests that this tactic was successful, that "by the middle of the nineteenth century, the highly ambivalent emotions aroused by subterranean sublimity had begun to yield to unambiguous appreciation of subterranean beauty. The image of artificial infinity gradually shed its aura of terror and assumed the mantle of enchantment" (Williams, 2008: 95). Taken at a broad scale, Williams tells us that "the central evolution in the aesthetic of the underworld between 1700 and 1900 is from ugliness to sublimity to magical beauty" (Williams, 2008: 83).

\footnotetext{
${ }^{1}$ The collodion process was introduced in the 1850s and largely replaced daguerreotype photography. In the collodion process, photographic material could be exposed and developed within a span about fifteen minutes in good light.
} 


\section{Contemporary Visual Ruptures}

"Engineers of the past and present might build sewers as rational spaces that bring waste to order, but it seems they will always be open to other subversive interpretations and uses..."

- Paul Dobraszczyk (2009: 192)

The magical beauty of sewers has been relayed in recent years by urban explorers who have ventured into systems laden with cameras, lights and tripods to create their own imagery. Urban exploration is a practice of researching and exploring off-limits spaces in the built environment (Arboleda, 2016; Bennett, 2011; Garrett, 2013; Mott and Roberts, 2013). Explorers are interested in making "discoveries that allow them to participate in the secret workings of cities and structures" (Ninjalicious, 2005: 3). Dedicated sewer explorers call themselves drainers (a drain being shorthand for sewage pipes, storm water channels or a combination of both in a combined system). The practice is an embodied negotiation of an intellectual preoccupation with space and time, where unseen, overlooked and underrepresented stories are framed through "spatialities of the aesthetic" (Hawkins and Straughan, 2015: 2).

An additional ambition for many urban explorers, in whatever locales they choose to trespass into, is to compound and complicate taken-for-granted environments by bringing the hidden to the fore, often through the creation of visual imagery disseminated publically. For explorers, "aesthetics are less a matter of judgement and more 'a matter of space and time"' (Hawkins and Straughan, 2015: 2, citing Ranciere 2006: 13). The creation of aesthetic assemblages by urban explorers thus becomes "a way of challenging the established codes, the ossified ways of seeing, saying, and sensing" (Paquette and Lacassagne, 2013: 256). The framework above can be applied to 
at a range of vertical points of the city that explorers trespass into, from bedrock to rooftop (Garrett, 2014; Garrett et al., 2016). However, this particular contribution to geography's "vertical turn" seeks to explore the unique encounters that reside through the portal of the manhole. Doing so becomes increasingly important the deeper cities sink (Dobraszczyk et al., 2016).

Consider Figure 3, an image created by three trespassers near the junction of the Southwest Storm Relief system with the River Effra, almost directly beneath Stockwell tube station in South London, at a place drainers call "Lucky Charms". Explorers encountered the junction by accident (hence the name), after walking upstream when they meant to walk downstream during a rare dry spell in the city. Behind the wall to the left, just out of frame, is the rushing River Effra, bordered by a rotting wooden retainer wall, which is cutting around a rusting piece of obsolete Victorian machinery perched on a small concrete island.

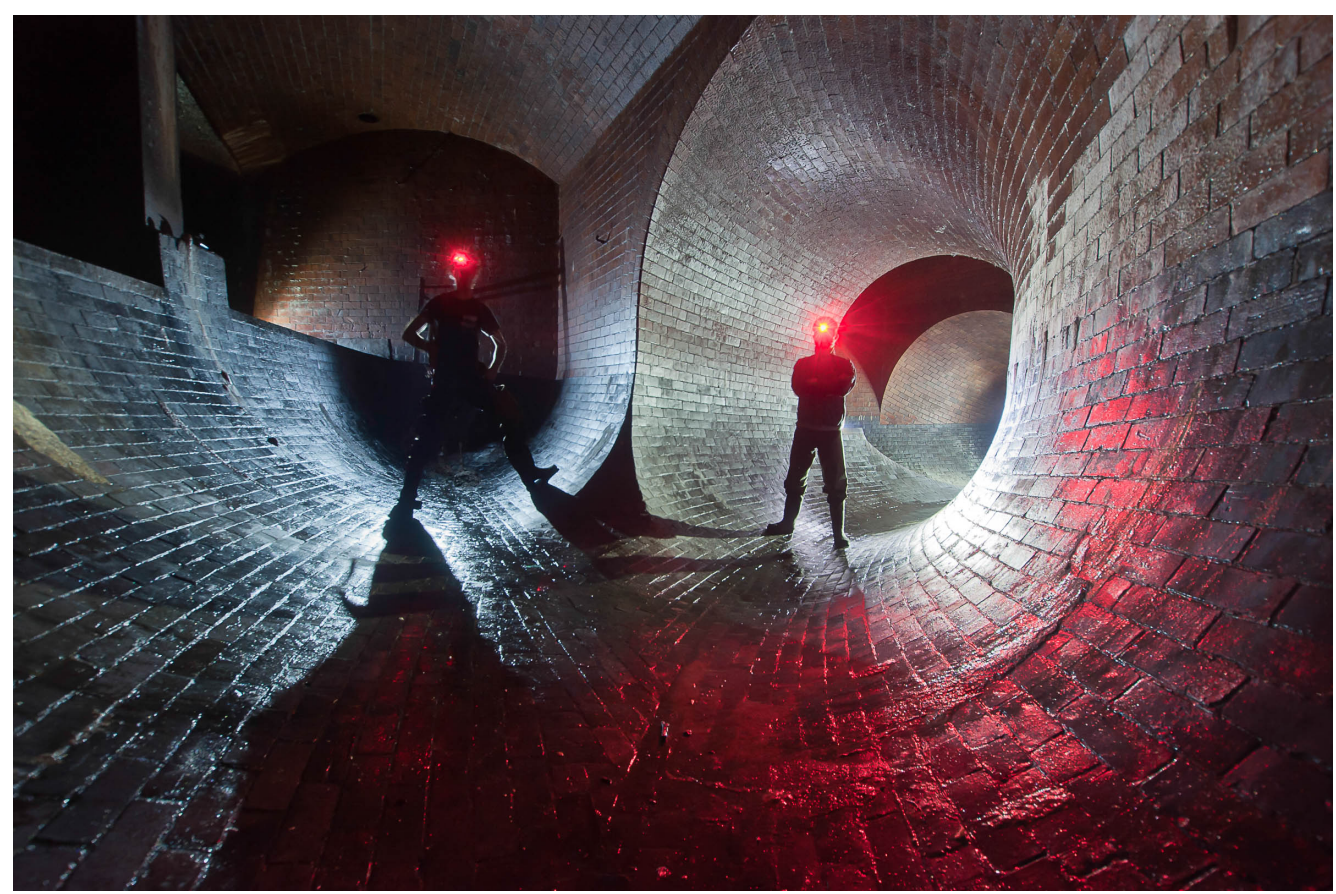

Figure 3. Yaz and the author in the River Effra, London (photo by Otter, Yaz and author). 
Although the image triggers a sensory imagination in interesting ways, it is also interesting because of consideration of the work happening outside the frame. For instance one might query the backstory of the three explorers and how they got there, the internal and external performative qualities of the image, or technical details such as method of lighting or the geographic proximity of this tunnel to cars above and trains below. Curiosity may be piqued by the possibility of waste from other South London bodies passing by (and likely into) the explorers via the river. One might wonder why a system built to be buried was so beautifully wrought and rendered. Certainly the explorers have gone into the system, in part, to consider and prompt consideration of such questions and the production of the photograph is clearly part of that effort.

The sewers of London have long been accessed legitimately by "flushers" who keep them flowing, a role still vital today, as indicted by the article's opening story of the fatberg. However, it was also clear from that anecdote that there is an exclusionary aspect to infrastructure, that only those who "need" to know can know. By entering the system without permission, explorers can, like flushers, come to understand where the system is coming under increased pressure, locating choke points, comprehending that “...today's infrastructure sustains the paranoid and waning civilization that will be tomorrow's ruin” (Rapp, 2010: 34).

After exploring dozens of channels in the system together, drainers explained to me that they felt they had become gatekeepers to intimate spatial knowledge about the urban environment most of the city's inhabitants were excluded from, a role both empowering and exciting. ${ }^{2}$ They felt that their engagement with hidden infrastructures was changing

\footnotetext{
${ }^{2}$ Ethnographic material in this article was collected during field research from 2008-2012.
} 
them and that they were creating new assemblages of bodies, spaces and technologies for other citizens to negotiate - taunting prompts. In short, drainers see their images not as documentary records but as indicators of possibility through potential aesthetic assemblages that are never in any sense complete, since the aesthetic is always contingent upon the context in which it is encountered.

These images form a refrain where they reframe the sewers as sublime or magical spaces - a nod to the epistemological conceptualisations of the subterranean past discussed above. However, time also courses through these practices in a more ontological sense. The reverence drainers exhibit for infrastructure, shared through photography, often rehearses historio-spatial knowledge in the replication of aesthetic forms embedded in those systems. The body-space interventions taking place through urban exploration activities thread formal and informal infrastructural histories of London across 150 years, where visual aesthetics play a key role in bringing the subterranean city to the imaginative fore, opening (more) participatory possibilities now and in the future. The power of vital infrastructure is revealed therefore not only as exclusive and utilitarian; photography exerts force on metric space that exceeds the intentions and expectations of the image-makers. Graham and Thrift (2007) suggest that Heidegger's tool-being theory helps us to understand how failing infrastructures become un-black boxed. Infrastructural systems, which the public are prohibited from embodied engagement with on an everyday basis, are tools ready-to-hand, disregarded until they break (also see Harman, 2002). In the same way that broken infrastructure ruptures the black-boxing of these systems, aesthetic practices also have the capacity to shock our awareness into recognition, or to cause fragile, withdrawn bodies to suddenly spring to the fore. 
Sewing up the city's skin

"Cities, like dreams, are made of desires and fears, even if the thread of their discourse is secret, their rules are absurd, their perspectives deceitful, and everything conceals something else."

-Italo Calvino (1972: 37)

Once London's Main Drainage was functioning as intended, the glamour of the new faded and "the mess, the dirt, the underbelly of the city, both socially and environmentally, became invisible and banned from everyday consciousness" (Kaika and Swyngedouw, 2000: 135). Just a decade after they were built, Bazalgette would have despaired to find that "underground sewerage pipes were not revisited" and that entry to them was now in fact barred (Kaika and Swyngedouw, 2000: 134). Now that the pipes had been put in place, the networks were no longer to be revered, visited and discussed but actively rendered "unseen".

The Victorian conceptualisation of the London sewers as a component of the urban body, read via both Chadwick and Bazalgette, bolstered the idea that what the Victorians built was literally the city's body. This notion was reinforced by the metaphorical sewing up of the skin that took place. The inevitably imperfect joinings between surface and subterranea, when cracked open, were soon considered analogous to a wound; broken city skin became a conduit of infection, the citizen body as potential host, the city's innards a ripe contamination zone. In the closure of the system, the biological and architectural became further melded (Gandy, 2004; Gandy, 2005) and that was all the more reason to push them from awareness. The obfuscation of the system was connected to modernist, and then neo-liberal, political projects promising 
greater efficiency through what many came to understand as functional ahistorical spaces of utilitarian infrastructures.

Yet in attempting to bury the history of urban sanitation, the atmospheric time-space of the sewers thickened, so that each rupture became densely laden with lingering affects. The longer the body was locked away, the more its qualities fermented - the sewers became charged, bloated with expectation. As Williams suggests above, anticipation is fundamental to sublimity. So when the seams of the city fractured and exposed glimpses of the underworld, the magical morphed once more into the sublime and tales of giant rats and reptiles, discarded murder weapons, floating corpses and clandestine conferences multiplied. Because everyday bodies were banned from the hidden rivers, public imagination populated them with other kinds of bodies.

Despite the bans, the public imagination, surely often piqued by a waft of subterranean air, ensured the hidden rivers of London sometimes crept back into frame. John Hollingshead, a writer commissioned by Charles Dickens, traversed London's sewer system in 1861 and invoked body metaphors, noting that "a piece of ordinary rust or of moist red brick is soon pictured as a trace of blood" (Hollingshead, 2009 [1862]: 4) in the sewer. Whilst venturing into a drain under a house he once owned in London's West End, he wrote that he "felt as if the power had been granted me of opening a trap-door in my chest, to look upon the long-hidden machinery of my mysterious body" (Hollingshead, 2009 [1862]: 62). Hollinghead's imaginative account, like a burst pipe, caused a rupture when published, as readers' bodies were suddenly transported into their own pipes. 
When the Fleet Ditch burst in 1862, flooding the new Tube system, a reporter for the The Illustrated Times suggested that the sewer was a "broken artery", the burst veins gushing the city's innards into the streets ("Bursting of the Fleet Ditch," 1862: 647, quoted in Dobraszczyk 2005: 369). Many people, like those on the pavement outside Blackfriars in the articles opening vignette, were fascinated by these ruptures and felt drawn to the obscure body. However, the interest in these ruptures was about more than curiosity over function or concerns about interruption in service, each rupture was also a reach into the past, harkening back to those original stories and images. The images and stories here "cohere, they hold together, without necessarily precipitating a held, an object. And each of these elements, even if encountered in isolation, functions as a catalytic trigger for the affective complex" (McCormack, 2012: 621).

Motivations of modern drainers - who work with words and images and more besides include desires for understanding the form, function and history of drains, coextending geographic accounts of the vertical city as a space of power and politics. As the explorer Bacchus explained to me, "I want to understand where the water goes when I flush my toilet; I want to see Bazalgette's bricks in action." In the River Tyburn, I stood underneath Buckingham Palace with a team of drainers, the faecal flow pinning our fishing waders to our legs. Bacchus, turning to the other drainers on the expedition said, "Boys and girls, you may never have tea with the Queen of England but you can now say you've stood in her shit." Hollingshead stood in the same place with hat in hand in 1868 and encouraged his expedition companions to join him in a rendition of God Save the Queen (Halliday, 2011). Events of this sort reveal a history we can touch (at times, we hope, not literally), they paint, 
not a big picture but a fragmented one: local, specific, incomplete, multiple, personal, erroneous perhaps, but scopic nonetheless ... Things are not in their place, there is jumble, clutter. We have to rummage around trying to find things (Hetherington, 2003).

Writers were not the only ones sneaking around underground after the skin was sewn up. "Toshers" also snuck into the newly-closed system, dragging with them sieves and shovels to illegally sift through the stream. Henry Mayhew, in London Labour and the London Poor, describes the toshers, or "sewer-hunters" as people who entered the sewers to explore them to considerable distance in the search for "tosh" - anything made of copper (Mayhew, 2010 [1861]: 184). They did not do so without risk; a $£ 5$ reward was offered to anyone who informed on trespassers entering the sewers without permission. Mayhew described the illicit wandering of the toshers as they crept through the underground stream, taking practical precautions:

Whenever [they] come near a street grating, they close their lanterns and watch their opportunity of gliding silently past unobserved, for otherwise a crowd might collect over head and intimate to the policeman on duty, that there were persons wandering in the sewers below (Mayhew, 2010 [1861]: 185-186).

The toshers of course caused another rupture, they provoked the public to once again consider the sewers as a body capable of harbouring other kinds of bodies and it was this passage that came to mind as I traversed a drain in London, covering my torch as I crept under a street grating, with a group of drainers headed out to photograph another 
feature "at the intersection of the imagined future and the imagined past" (DeSilvey, 2012: 35). Later in the library, looking at the photograph we made and recalling to those aesthetic assemblages so carefully constructed by Bazalgette - the glistening bricks, the slinky architectural lines and the unnecessarily beautiful ironwork - I felt that we were still caught up in Bazalgette's 150-year old public relations campaign, that we had fallen victim to a lingering sensory cocktail. The thought passed but I was left with a residue. Later, at Bazalgette's bust on the North Embankment of the River, I asked the other drainers how they thought the engineer would respond to them photographing the sewers. One of them replied, "I don't know what he wanted but I feel like he's in there somewhere." For drainers, there's a sense that the ghost of Joseph Bazalgette is forever haunting the body he constructed, that the "presence of the past in a present" (Augè, 1995: 75) was inevitable, regardless of effacing efforts. 
More Bodies in Bodies

As in Paris, $19^{\text {th }}$ century images of the London Sewers were both affective triggers and enticements to participation, for there were also opportunities for first-hand viewing where Bazalgette spun his sensory web. On $8^{\text {th }}$ and $9^{\text {th }}$ October 1861 , he invited various London elites to see the sewers for themselves during tours where he delivered rousing speeches (Dobraszczyk, 2009: 101). Subterranean spaces were constructed to impress, full of "elaborate interior decorative ironwork" and striking external architectural features (Dobraszczyk, 2007: 354). Attention to detail was key. As Peter Ackroyd (2012: 78) writes, even "in the [sewer] tunnels themselves there [was] much elaborate architectural detailing and decoration".

In 1862, William Webster, one of Bazalgette's sub-contactors, hosted a dinner party in the sewer to celebrate the completion of the Southern Outfall. At the event, "the immense circular pipeline had been given a temporary floor so that it resembled an extremely long, arched crypt. The floor extended for a mile along the tunnel and was lit on either side by lamps, flickering against the red brickwork" (Rule, 2012: 35). Clearly, this party has been carefully engineered to leave a lasting impression. This did not go unnoticed; the press of the time expressed concern about Bazalgette and Webster's choice of lighting. The thousand of lamps placed strategically in the archways to bring out the brickwork was meant to overload the senses. But it also, in the eyes of one journalist, transformed visitors into dim shadowy figures through chiaroscuro, the play of light on surfaces, conjuring predictable spectres of the underground (Dobraszczyk, 2009: 184). 
In Figure 4, we can see various luminaries, including the Prince of Wales, congregating under the arches of Bazalgette's sewage tunnels. Hundreds, if not thousands, of lights are stencilled by the artist, who has also clearly spent an incredible amount of time inking the lines on the bricks. What is interesting about the drawing is less what it accounts for "factually" and more the sense that it relays through the thoughtful rendering of particular details.

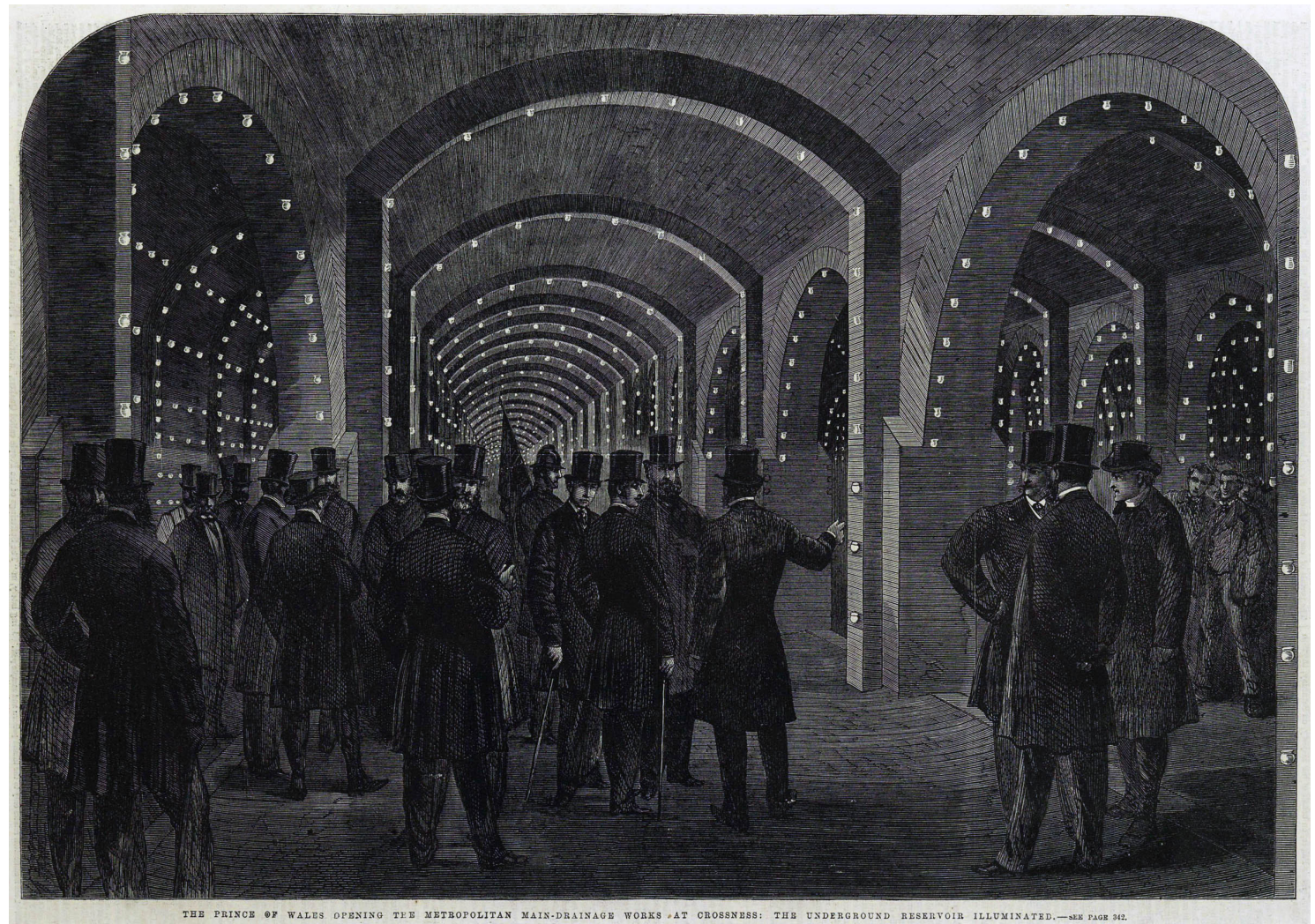

Figure 4. A subterranean gathering of socialites, Crossness Pumping Station, Illustrated London News, April 15th 1865, p. 348 (image via Wikimedia Commons).

In the process of public engagement during the course of his taxpayer-funded architectural experiment, Bazalgette carefully engineered aesthetic assemblages. While there was clearly an experiential element to his sales pitch, the most important component of the package was the affective. Manipulation of the senses here went hand-in-hand with a coordination of atmospheres and imaginaries that suggested 
endless openness, a feeling that nothing would or could or should ever be the same. Bazalgette was producing a new urban sensibility that he expected would overwhelm taboo, suspicions and misgiving, through novel assemblages of technologies and bodies.

Although they are functional, active spaces, sewers shimmer on the edge of abandonment and decay, in a state of consistent benign neglect and have qualities of dereliction, where "spatial and temporal indicators are fused... Time, as it were, thickens, takes on flesh, becomes artistically visible; likewise, space becomes charged and responsive to the movement of time, plot, history" (Bakhtin, 1981: 84). It is in the slippery intersection of time and space found in the sewers that urban explorers seek to enfold themselves. Through the process of research, exploration, discovery and dissemination, explorers find a knot of other times, other people and other places that reform subjectivities along unanticipated lines, meld moments when the body and the urban body become entangled, inseparable, irrefutable, inarticulable.

In part because of the theological and moral associations that the underground harboured, aesthetics always played an important role in urban subterranea. The sociotechnical assemblages formed through bodies in sewers are embedded in the architecture of the networked city in alluring, if obtuse, anamnesis. The aesthetic tradition of these spaces is also rife with contestation, with regard to the manipulation of this imagery for political ends, the politics surrounding the rendering of these spaces closed to public access and of course in the inevitable embodied and visual subversion of those spatial disciplining regimes. Clearly the work that these images do (both contemporary and historical) is not simply about depiction and documentation. Distance between the surface and subsurface city is closed by proximal imagery that does the 
work of connecting matter and history, making clear that sewers are neither atemporal nor aspatial. Relational understandings here are not an "animation" of passive matter these spaces accumulate regardless and are drawn out by the incorrigible attachment of the imagination.

There is an aesthetic politics of urban exploration both in what these images picture and in how they picture, the kinds of intellectual labour they do in their capture and release. Latham and McCormack (2009: 253) describe this bursting of possibility as a kind of "affective intensity: [images] make sense not just because we take time to figure out what they signify, but also because their pre-signifying affective materiality is felt in bodies". These body-environment relations are precisely what we encounter in considering the critical concerns of the journalist who felt Bazalgette and Webster were manipulating future imaginations of the Crossness Pumping Station event by playing tricks with light and shadows.

The images that drainers produce, shot through with tangled associations, once distributed, begin to effect, in ways not at all quantifiable, relationships to place, just as they did in the past. This aesthetic infolding inculcates a sense of participation that is historically aware, socially engaged and politically promising. Each photo that explorers produce and share inevitably triggers century-old associations and provoke unbidden memories and nervous anticipations of possibility. Part of this is about bringing the hidden to the fore; opening up spatial imaginations, compounding imaginaries, but it is also about creating a sense of vertical movement. The images make it clear that nothing is more haunting than the present.

Exempli gratia: consider figures 5 and 6, keeping in mind that figure 6, a photo taken by five drainers, was taken before we knew of figure 5, which was found in the archives 
during the course of research for this paper. Aside from the obvious "facts" that it appears five flushers took this photo 60 years before we did at the same junction in the River Fleet, the framing and staging of the shot is remarkably similar. While we might be tempted to call this a coincidence, or indeed to suggest both groups were duped by Bazalgette, who obviously designed this junction to be noticed, the unintentional replication of aesthetics here is striking.

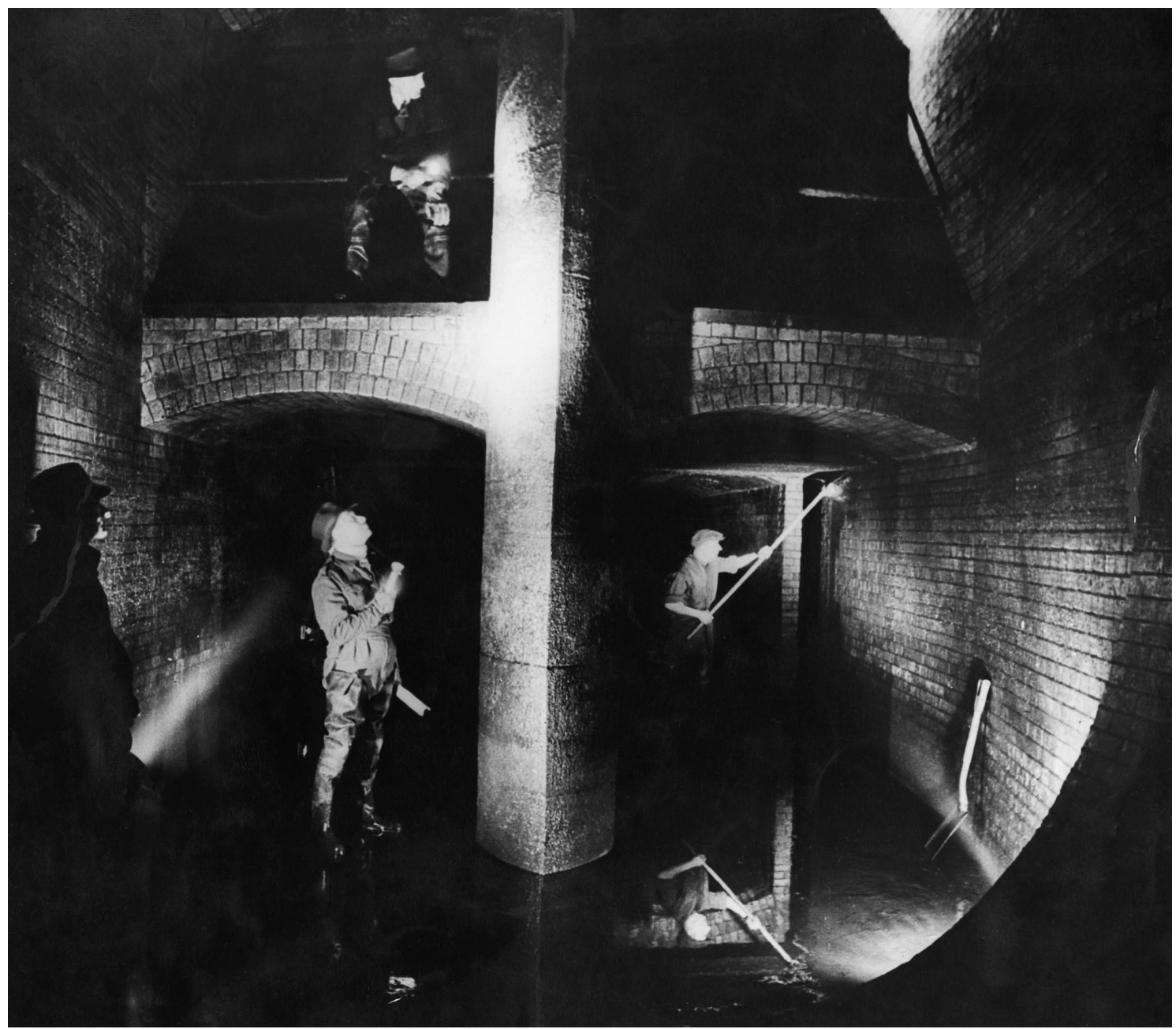

Figure 5. Flushers in the River Fleet under Farringdon Road, London, 15th April, 1950, Picture Post (image via Getty Images, used with permission. 


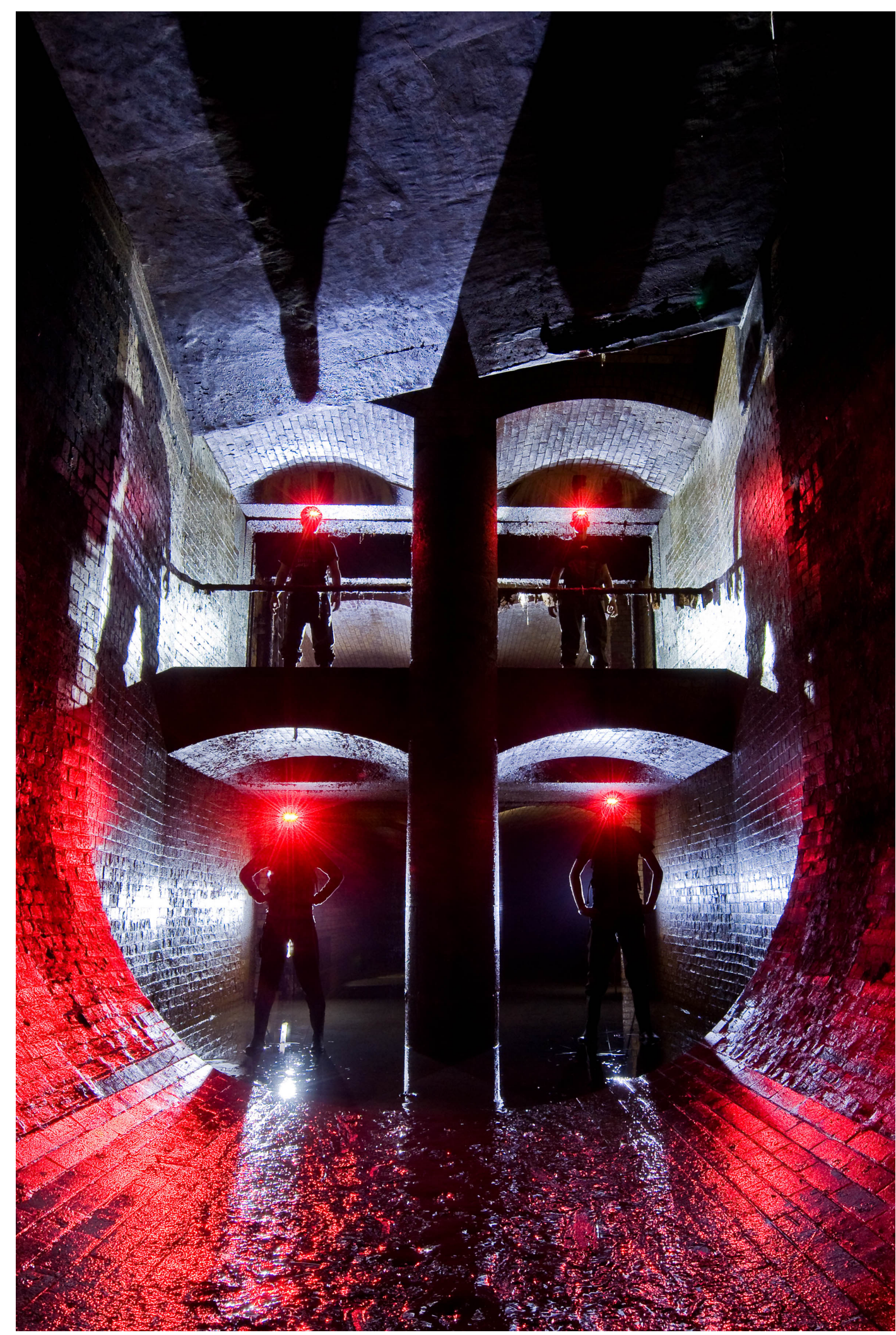

Figure 6. Urban explorers in the River Fleet under Farringdon Road, London, 20th August 2012 (photo by Luca Carenzo, Marc Explo, Helen Carlton, Matthew Power and author). 
Just as when drainer images are shared, they become enmeshed in aesthetic ancestries, so was this image. It was in us before we even opened the manhole cover, dormant in that pipe, affectively accreting. The original image achieved escape velocity when it was compounded by the new encounter and that inevitably affected us, wrapped as we were in the embodied experiences of place. And since geographical aesthetics also calls for speculation, imagine this scenario playing out again in another 50 years in the future when someone photographs this junction again (maybe as a ruin) and then discovers this paper.

Explorer imagery encourages thinking about the relationship "formed from within heterogeneous materialities of bodies, technologies and places" (Anderson and Harrison, 2010, 18). Most drainer photos are carefully crafted, like those commissioned by Bazalgette, and often composed by three people: one to backlight the scene, one to block the light, creating a halo around the explorer that bounces off the brick, and another to tweak the camera settings and hit the shutter release. The knowledge obtained from the production of the photos (but not necessarily about the photos) prompts us to ask different sets of questions about the material we encounter in the archive, to sidestep representational and descriptive analysis in favour of an aesthetic reading. It is critical to thread the implications of the aesthetic lineage outlined above; it is just as much a part of these places as the bricks hold them together.

Never will the same sewage be photographed twice; never will the same explorer take the same photo, yet all are linked through a unique grammar. Like the media produced by architecturally-engaged Victorians, these photos are an invitation to imagine and contemplate the urban body and to, if you so choose, participate in its inner workings. Draining filaments dusty archives through stinky street gratings and continues the work 
of realising potentials for "cyborgian conceptions of the city (that) emphasize the continuing political salience of the public realm" (Gandy, 2005: 41). Exploration of hidden infrastructure reminds us that, "The system is alive, adapting... shaped by the very drive that impels us to explore it, too vast and promiscuous to be fully known, but always rewarding further searches" (Deyo and Leibowitz, 2003: 28). The touching, feeling, doing, experiencing and sharing behind draining,

...has the capacity to dissolve boundaries, to make proximate that which was far away, and in doing so not only rearrange our metaphysics of intimacy and distance, but pose a danger to any and all systems of order that rely upon distinction and separation. These bodies 'resist, exaggerate, and destabilize distinctions and categories that mark and maintain bodies'... 'signifying pleasure and desire as sites of insurgency' (Dixon and Straughan 2010: 454, referencing Springgay, 2003).

\begin{abstract}
Although, as Rule suggests, "underground London is largely Victorian” (Rule, 2012: 9), the history of subterranean London is in a constant state of re-imagination. In the context of that Victorian aesthetic legacy, what contemporary urban explorers discover and share holds value beyond localized exploration events or glossy media spectacles; the multiple knowledges that explorers open out allow people to inhabit the city in novel vicarious and visceral ways.
\end{abstract}

Armed with this knowledge, the future of London drain exploration and photography, perhaps taking place in the London Tideway Tunnel mentioned at the beginning of this paper, a 7.2-metre diameter "super sewer" running from Hammersmith to Beckton at a 
70-metre depth, takes on weight as more than a subversive practice of documenting fresh bore. In the "seamless skin" tradition, there will be very little public invitation to embodied participation with the new construction, making the role of the curious subterranean wanderer and rogue documentarian even more vital. ${ }^{3}$ More importantly however, the stories and images of those explorations are "the experiences, practices and textures of vertical life" (Harris 2015: 608), already temporal charged, homage to the multivalent and often unexpected underground histories of our cities.

Stephen Graham and Lucy Hewitt (2012: 72-73) have suggested consideration of underground infrastructure infrastructures as a means of undermining a "flattening of discourses and imaginaries [that] tends still to dominate critical urban research in the Anglophone world", a view of the world that recognizes problems associated with urban sprawl, for instance, whilst often ignoring the layers of sprawl beneath and above us (also see Graham, 2016). The vertical turn is geography is afoot, prompting renewed considerations of how infrastructures and technologies are transforming our relationships to cities. And yet, as Stuart Elden, Gavin Bridge, and Andrew Harris have all suggested, it is important that we keep the horizontal topologically joined as we make our vertical moves (Bridge, 2013; Elden, 2013; Harris, 2015). Geographical aesthetics thus offers a way of not just better knowing verticality but engaging with it as producers and co-producers of temporally-infused spheres of meaning by taking a crowbar to the black box of infrastructure.

\footnotetext{
${ }^{3}$ Although some infrastructure is accessible during annual "open house" weekends, the tours are tightly controlled, often limiting the sights-within-sites to see, not to mention the constricted range of sensory and affective indulgences a guided tour affords.
} 


\section{References}

Ackroyd P, 2012 London Under (Vintage, London)

Adey, P, 2013 "Securing the volume/volumen: Comments on Stuart Elden's Plenary paper "Secure the volume" Political Geography 34 52-54

Arboleda P, 2016, "Heritage views through urban exploration: the case of "Abandoned Berlin'" International Journal of Heritage Studies Online First 1-14

Augè M, 1995 Non-places: introduction to an anthropology of supermodernity (Verso, London)

Bakhtin M, 1981 The Dialogic Imagination (University of Texas Press, Austin, Texas)

BBC, 2013, "'Bus-sized fatberg' removed from London sewer",

(http://www.bbc.co.uk/news/uk-23584833 accessed 16th August 2013)

Bennett L, 2011, "Bunkerology - a case study in the theory and practice of urban exploration" Environment and Planning D: Society and Space 29 421-434

Bridge G, 2013, "Territory, now in 3D!" Political Geography 34 55-57

"Bursting of the Fleet Ditch", 1862, The Illustrated Times, pages 139-140

Butcher, Melissa (2011) "Cultures of Commuting: The Mobile Negotiation of Space and Subjectivity on Delhi's Metro", Mobilities, 6 (2): 237-254

Calvino I, 1972 Invisible Cities (Faber and Faber, London)

Chadwick E, 1842 Report on the Sanitary Conditions of the Labouring Population of

Great Britain (London)

Cook C G, 2001, "Construction of London's Victorian sewers: the vital role of Joseph

Bazalgette" Postgraduate Medical Journal 77 802-804

Deleuze G, 1997, "City/State", in Rethinking Architecture: A Reader in Cultural Theory

Ed N Leach pp 294-299

DeSilvey C, 2012, "Making sense of transience: an anticipatory history" Cultural

Geographies 19 31-54

Deyo L B, Leibowitz D, 2003 Invisible frontier: exploring the tunnels, ruins, and rooftops of hidden New York (Three Rivers Press, New York)

Dixon D P, Straughan E R, 2010, "Geographies of Touch/Touched by Geography"

Geography Compass 4 449-459

Dobraszczyk P, 2005, "Sewers, wood engraving and the sublime: picturing London's main drainage system in the Illustrated London News, 1859-62" Victorian Periodicals

Review 38 349-378

Dobraszczyk P, 2007, "Architecture, ornament and excrement: the Crossness and

Abbey Mills pumping stations" The Journal of Architecture 12 353-365

Dobraszczyk P, 2009 Into the Belly of the Beast: Exploring London's Victorian Sewers

(Spire Books Ltd, Reading)

Dobraszczyk P, Galviz C L, Garrett B L, 2016 Global Undergrounds: Understanding

Cities Within (Reaktion, London)

Elden S, 2013, "Secure the Volume: Vertical geopolitics and the depth of power"

Political Geography 34 35-51

Gandy M, 1999, "The Paris sewers and the rationalization of urban space " Transactions of the Institute of British Geographers 24 23-44

Gandy M, 2004, "Rethinking urban metabolism: water, space and the modern city"

City: analysis of urban trends, culture, theory, policy, action 8 363-379

Gandy M, 2005, "Cyborg urbanization: complexity and monstrosity in the

contemporary city" International Journal of Urban and Regional Research 29 26-49

Garrett B, 2014 Subterranean London: Cracking the Capital (Prestel/Random House, London) 
Garrett B, Moss A, Cadman S, 2016 London Rising: Illicit Photos from the City's Heights (Prestel/Random House, London)

Garrett B L, 2013, "Undertaking recreational trespass: urban exploration and infiltration" Transactions of the Institute of British Geographers 39 1-13

Graham S, 2000, "City A-Z", Eds N Thrift, S Pile (Routledge, London)

Graham S, 2009 Disrupted Cities: When Infrastructures Fail (Routledge, London)

Graham S, 2016 Vertical: The City From Above and Below (Verso, London)

Graham S, Hewitt L, 2012, "Getting off the ground: On the politics of urban verticality"

Progress in Human Geography 37 72-92

Graham S, Thrift N, 2007, "Out of order: understanding repair and maintenance"

Theory, Culture \& Society 24 1-25

Halliday S, 2011 London (Amazing and Extraordinary Facts) (David \& Charles, London)

Hardy A, 1984, "Water and the Search for Public Health in London in the Eighteenth and Nineteenth Centuries" Medical history 28 250-282

Harman G, 2002 Tool-Being: Heidegger and the Metaphysics of Objects (Open Court, Chicago and La Salle, Illinois )

Harris A, 2015, "Vertical urbanisms: Opening up geographies of the three-dimensional city" Progress in Human Geography 39 601-620

Hawkins H, Straughan E, 2015 Geographical Aesthetics: Imagining Space, Staging

Encounters (Ashgate, London)

Hetherington K, 2003, "Spatial textures: place, touch, and praesentia" Environment and Planning A 35 1933-1944

Hinchliffe S, 1996, "Technology, power, and space - the means and ends of geographies of technology" Environment and Planning D: Society and Space 14 659682

Hollingshead J, 2009 [1862] Underground London (Kessinger Publishing, London) Kaika M, Swyngedouw E, 2000, "Fetishizing the modern city: the phantasmagoria of urban technological networks" International Journal of Urban and Regional Research 24 120-138

Mau B, 2003 Massive Change (Phaidon, London)

Mayhew H, 2010 [1861] London Labour and the London Poor (Oxford University

Press, Oxford)

McCormack D, 2012, "Thinking in Transition: The Afirmative Refrain of Experience/Experiment", in Taking-Place: Non-Representational Theories and Geography Eds B Anderson, P Harrison (Ashgate, Surrey, England)

McFarlane C, Rutherford J, 2008, "Political Infrastructures: Governing and Experiencing the Fabric of the City" International Journal of Urban and Regional Research 32 363-374

Mott C, Roberts S, 2013, "Not Everyone Has (the) Balls: Urban Exploration and the Persistence of Masculinist Geography" Antipode 46 229-245

Ninjalicious, 2005 Access all areas: a user's guide to the art of urban exploration (Infilpress, Canada)

Paquette J, Lacassagne A, 2013, "Subterranean subalterns: Territorialisation, deterritorialisation, and the aesthetics of mining" Culture and Organization 19 242-260 Pyke D L, 2005 Subterranean cities: the world beneath Paris and London, 1800-1945 (Cornell University Press, Ithica)

Rancière J, 2006 The Politics of Aesthetics: The Distribution of the Sensible (Continuum, New York) 
Rapp A, 2010 The esoteric city: urban exploration and the reclamation of the built environment, Architecture, New York School of Visual Arts, New York

Rule F, 2012 London's Labyrith (Ian Allen Publishing, Hersham, Surrey)

Springgay S, 2003, "Cloth as intercorporeality: touch, fantasy, and performance and the construction of body knowledge" International Journal of Education \& the Arts 4

Vidler A, 1990, "The building in pain: the body and architecture in post-modern culture" Architectural Association School of Architecture 19 3-10

Wiles W, 2014, "The Concrete Tangle" Aeon Magazine, 17 July

Williams R, 2008 Notes on the underground: an essay on technology, society and the imagination (MIT Press, Cambridge, MA) 